\title{
Construction on Practical Teaching System for Applied Undergraduate from the Perspective of Key Competencies
}

\author{
Xiangdong Zhang \\ Shenyang Institute of Science and Technology, Shenyang, 110167, China \\ 2060602@qq.com
}

Keywords: key competencies; applied undergraduate; practical teaching system; implementing countermeasures

\begin{abstract}
Practical teaching is an effective way to consolidate theoretical knowledge and deepen theoretical understanding, and is an effective means to improve students' core literacy. Based on the core literacy of Chinese students, this paper builds an application-based undergraduate practice teaching system based on core literacy, including "Engineering cognitive platform, Course experiment platform, Practice training platform, Graduation design platform, Scientific experiment platform, and Social practice platform". Etc., and puts forward the "focus on core literacy cultivation, build a diversified practice teaching base, strengthen the construction of practical teaching faculty, integrate practical curriculum system according to practical teaching objectives, promote the use of project practice law, improve the social environment of practical teaching management, and improve practical teaching and specific implementation measures such as quality control system and dynamic adjustment of practical teaching content.
\end{abstract}

\section{Introduction}

Core literacy is a must-have character and key ability that students gradually adapt to the needs of their lifelong development and social development in the process of receiving the corresponding semester education. Core literacy is a combination of students' knowledge, skills, emotions, attitudes and values. It focuses on students' understanding in the process of training, rather than result-oriented. Core literacy is both stable, open and developmental. A dynamic optimization process that is accompanied by sustainable development for the whole life and advancing with the times is the basic guarantee for individuals to adapt to the future society, promote lifelong learning, and achieve all-round development.

Ordinary undergraduate and applied undergraduate courses are two types of undergraduate education, and the relationship between the two should be parallel development. Compared with the general undergraduate, the applied undergraduate has distinct technical application characteristics. In terms of training specifications, the undergraduate students are trained to adapt to the high-level technical application talents needed for the first line of production, construction, management and service; in the training mode, the undergraduate course is applied to meet the needs of the society, and the students are trained to develop the technical application ability. The knowledge, ability, quality structure and training program build the curriculum and teaching content system with the main purpose and characteristics of "application", and attach importance to the cultivation of students' technical application ability.

Practical teaching is an effective way to consolidate theoretical knowledge and deepen theoretical understanding. It is an important link for cultivating high-quality applied talents with innovative consciousness, and is an important platform for cultivating students to master scientific methods and improve application capabilities. Through practical teaching, enrich and activate students' scientific thoughts, deepen their understanding of theoretical knowledge, cultivate students' ability to observe and analyze the objective world, and understand the status and role of practice in the development of scientific theory. The important way to cultivate applied talents is practice teaching. The application of undergraduate practice teaching under the core literacy 
perspective has new connotation. The research content of this paper not only enriches the application of undergraduate practice teaching system, but also explores the application-oriented undergraduate practice teaching theory.

\section{Chinese Students Develop Key Competencies}

The core literacy of Chinese students' development is centered on the cultivation of "all-round development" and is divided into three aspects: cultural foundation, independent development and social participation. Among them, the cultural foundation emphasizes the ability to acquire knowledge and skills in various fields such as humanities and sciences, master and apply the achievements of human excellence, cultivate the inner spirit, pursue the unity of truth, goodness and beauty, and develop into a broad cultural foundation with a higher spirit. The pursuit of people; independent development, emphasis on the ability to effectively manage their own learning and life, to recognize and discover self-worth, to explore their potential, to effectively cope with the complex and ever-changing environment, to achieve a brilliant life, to develop a clear direction of life and life People of quality; social participation emphasizes the ability to handle the relationship between self and society, develop moral norms and codes of conduct that modern citizens must abide by and fulfill, enhance social responsibility, enhance the spirit of innovation and practice, and promote personal value. Promote social development and progress, and develop into people with ideals and convictions. The above three aspects are comprehensively expressed as the six basic qualities of humanistic heritage, scientific spirit, learning to learn, healthy living, responsibility, and practice innovation, and are specifically refined into 18 basic points such as national identity. The specific structure is shown in Fig. 1.

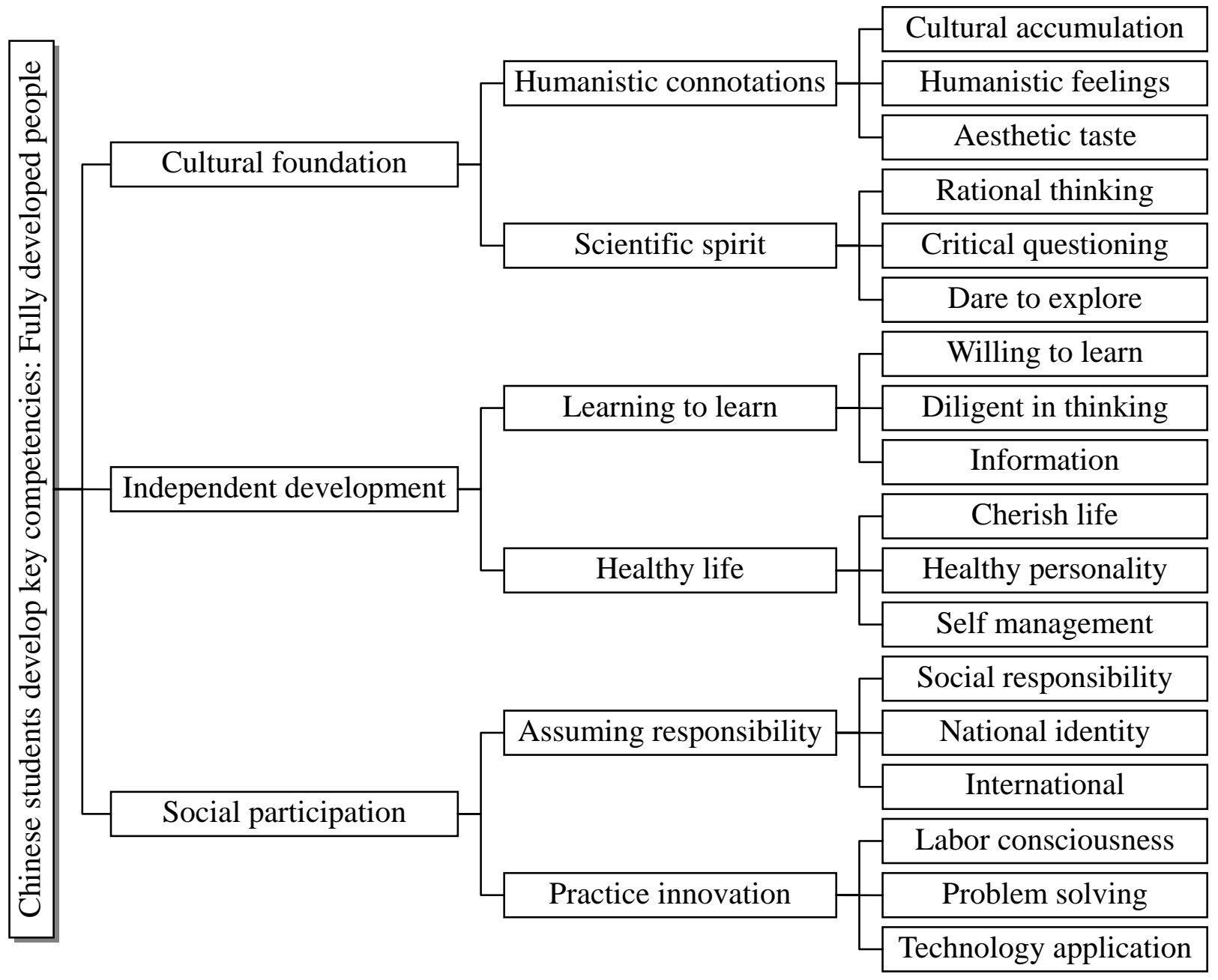

Fig. 1. Composition on Chinese students develop key competencies 


\section{Practical Teaching System for Applied Undergraduate from the Perspective of Key Competencies}

The practical teaching system is an organic whole composed of various elements in practical teaching. The scientific and reasonable practical teaching system not only teaches students practical knowledge, verification theory and training practical skills, but also reflects the combination of theory and practice, guides students to master scientific thinking, improve analytical and problem-solving skills, and cultivate innovative spirit and practical ability. . The application-based undergraduate practice teaching system under the core literacy perspective proposed in this paper consists of the following six aspects, as shown in Fig. 2.

\begin{tabular}{|c|c|c|}
\hline Engineering cognitive platform & \multirow{3}{*}{$\begin{array}{l}\text { Practical teaching } \\
\text { system for applied } \\
\text { undergraduate in } \\
\text { the perspective of } \\
\text { key competencies }\end{array}$} & Graduation design platform \\
\hline Course experiment platform & & Scientific experiment platform \\
\hline Practice training platform & & Social practice platform \\
\hline
\end{tabular}

Fig. 2. Component on practical teaching system for applied undergraduate in the perspective of key competencies

(1) Engineering cognitive platform. It consists of system components of engineering cognition, which fosters students' engineering system concepts and stimulates students' curiosity and interest in the profession. Under the background of rapid development of global technology economy, increasingly fierce competition for talents, and continuous improvement of employer standards, students of science and engineering colleges should use the engineering cognition platform to continuously expand the knowledge field and focus on cultivating engineering quality, in addition to mastering the necessary In addition to theoretical and practical knowledge, we should also take the initiative to adapt to the market and establish management awareness, quality awareness, innovation awareness, safety awareness, marketing awareness, group awareness, environmental awareness and legal awareness.

(2) Course experiment platform. It consists of modules, curriculum design and comprehensive design of course modules to cultivate students' scientific and standardized learning methods. Most of the science and engineering colleges, except for some basic courses, have higher utilization rates of experimental equipment, and other types of utilization are not high. In the case of limited resources, improve the efficiency of the use of experimental equipment, through the upgrade of the original experimental equipment, provide experimental support for the series of courses, to achieve a platform of multiple course sharing experimental, which is an effective solution. It can not only ease the current situation of shortage of experimental equipment, but also solve the problem of increasing equipment under the condition of space shortage.

(3) Practice training platform. Internship is to arrange students directly to work, study at work, more suitable for vocational training based on hands-on operation. Through the internship platform, the theory and practice are linked to enhance students' ability to find problems and analyze problems, and strengthen thinking training. Training is a concept established with the cultivation of applied talents. Training is a simulation process that requires both an environment and a copy. In the teaching process, we should combine theory with practice, and emphasize students' participatory learning, and improve students' professional skills, practical experience and working methods in a short period of time.

(4) Graduation design platform. Graduation design is the last practical teaching link in the undergraduate talent training program. It integrates the knowledge system learned during the university, which is to achieve the goal of talent training, improve students' application ability and innovative thinking, and test students. An important means of comprehensive quality. Through the graduation design platform, the computerized network management of the whole process of graduation design is realized, the students directly upload materials, and the teachers guide the network to reduce the management cost of the graduation design. Teachers can monitor the 
graduation design process at any time, improve the efficiency of graduation design guidance, and make graduation design management more scientific and efficient.

(5) Scientific experiment platform. It consists of open experiment, discipline competition, innovation and entrepreneurship. It is a supplement and extension of teaching experiment, and it is an effective way for students to use their spare time to cultivate practical ability. Through scientific and technological experiments, students' interest in professional courses will be enhanced, students' hands-on ability will be exercised, and teaching experiments will be supplemented and enriched. The technology experiment platform is based on modular composition, with high expandable and versatility, which is convenient for students to combine modules for different functions during extracurricular technology practice, and realize their own scientific experiment projects with optimal solutions, which is beneficial to the whole. The quality of teaching is improved.

(6) Social practice platform. Social practice is that college students use their spare time, extensively contact with the society, improve their understanding of the status quo of economic and social development, realize a better combination of book knowledge and practical knowledge, and help them establish a correct world view. A view of life and values, a useful activity that contributes to society while improving one's ability. From the perspective of social practice, it can be divided into in-school practice and off-campus practice; from the perspective of social practice, it can be divided into organized practice activities and students' spontaneous practice activities; from the perspective of social practice, it can be divided into paid Sexual practice and unpaid practice.

\section{Implementing Countermeasures on Practical Teaching System for Applied Undergraduate from the Perspective of Key Competencies}

The cultivation of applied talents is the practical need of higher education to serve economic construction. Practical teaching is an important means to improve the training mode of applied talents. According to the current situation of applied undergraduate practice teaching, with reference to the research results of predecessors and the realistic requirements of core literacy, the specific application strategies proposed in this paper are as follows:

(1) Focus on the cultivation of core literacy. The concealment and expansion of core literacy in textbooks, the ambiguity and continuity presented in teaching objectives, and the implicit and dynamic nature of student evaluation indicators put new demands on teacher teaching. In the process of teaching, we actively promote the reform of teaching methods so that students can freely develop space. Make full use of the advantages of practical teaching, stimulate students' initiative and participation in the teaching process, apply theoretical knowledge to teaching practice, improve students' comprehensive quality and practical work ability, and cultivate students' innovative consciousness and innovative ability.

(2) Build a diversified practice teaching base. The practice teaching base is a necessary condition for carrying out practical teaching and an important guarantee for strengthening the practical teaching link. Try to build a diverse practice base to meet the needs of application capacity development. First, the practice base in the school is mainly to verify the practical teaching and promote the understanding of theoretical knowledge, which is a supplement and extension of theoretical teaching. Second, the school and the enterprise jointly build a practice base. The enterprise provides the necessary resources, equipment and teachers. The teachers and students assist the enterprise to complete the technical work. This is a practical teaching model for both schools and enterprises.

(3) Strengthen the construction of practical teaching faculty. Strengthening the construction of practical teachers is a key to comprehensively improving the quality of practical teaching. Colleges and universities should focus on professional practice teaching reform, attach importance to the construction of teachers, guide teachers to change educational concepts, strengthen management and policy support for practical teaching; continuously promote the professional ability of practical teaching teachers, comprehensively focus on professional quality, teaching ability, and educational technology. Practical training in areas such as professional skills, applied technology and innovative capabilities. Pay attention to the construction of teachers' practice training base, and provide 
conditions for teachers to take up their duties.

(4) Integrate the practical curriculum system according to the practical teaching objectives. Combine or withdraw repetitive experiments, increase comprehensive and design experiments, and realize the integration of practical teaching; practice all aspects of practical teaching activities throughout the whole process of learning, and build practical teaching that is successively undertaken and complemented in function. System, and make the practice links in the best state in terms of time arrangement and mutual cooperation, and realize the whole process of practical teaching; follow the four steps of cognitive internship, basic skill training, professional skill training, and vocational comprehensive ability training, step by step Arrange practical teaching links and strengthen the gradual progress of practical teaching.

(5) Promote the use of project practice methods. The project practice method is a teaching practice activity carried out by teachers and students by jointly completing a complete project. The specific method is: the teacher contacts the cooperation unit, signs the project cooperation contract; divides the students into several groups, clarifies the role and role of each person in the group; formulates the project plan and cooperates with the enterprise to actually operate the project; the enterprise is responsible for the scoring and application of the program And put forward new problems in the application, the teacher summed up the implementation of the project. The project practice method not only can exercise the students' practical ability, but also achieve the purpose of mutual benefit with the enterprise.

(6) Improve the social environment of practical teaching management. At present, there is a lack of policies and regulations that encourage social support for practical teaching and social practice in universities. In the face of the practical difficulties of universities and enterprises to build internship bases, local governments have not taken strong measures, and enterprises and institutions lack the enthusiasm to accept the practice of college students. The government also lacks relevant supporting policies, lacks investment in practical teaching, and lacks the executive power of supervision. Therefore, it is necessary for the state to pass legislation to introduce policies and regulations that encourage enterprises and all sectors of society to support colleges and universities to practice teaching, and to improve the social environment for practical teaching management in colleges and universities.

(7) Improve the quality control system of practical teaching. Practice teaching is a systematic project, and it is necessary to establish a practical teaching coordination mechanism for coordination and unified management. The major decision-making colleges that practice the daily management of teaching propose specific plans and submit them to the College Teaching Work Committee for research and decision. The Academic Affairs Office needs to formulate a practical syllabus according to the professional training program, improve the management system, implement monitoring and management of the implementation and organization of all aspects of practical teaching, and monitor the quality and effectiveness of the practical teaching process through a series of practical teaching management systems. In time, propose improvement measures for the problems found.

(8) Dynamically adjust the content of practical teaching. Practical teaching is an improvement of theoretical teaching, an important means of applying theory to practice, focusing on the cultivation of students' practical application ability and the improvement of job skills. The teaching content of practical teaching is closely related to production technology. With the improvement of technology level and the development of new technology, the content of practical teaching should be increasingly enriched. Applied undergraduate colleges should focus on improving professional practice skills, dynamically adjust the content of practical teaching, pay attention to core literacy and innovation ability training, and establish a dynamic adjustment mechanism for practical teaching of school-enterprise linkage.

\section{Acknowledgement}

This work is supported by Liaoning educational science project for the 13th Five Year Plan (JG18DB409): Research on reform and application of practical courses for applied colleges and 
universities in the perspective of key competencies.

\section{References}

[1] S. C. Lan, "Research on the present situation and Countermeasures of practical teaching in application oriented Universities," Journal of Hunan City University (Natural Science), vol. 25, no. 6, pp. 270-271, 2016.

[2] N. Li, F. Jia, H. Y. Yang, Z. Zhao, "The difficulties and Countermeasures of the reform of practical teaching in China's colleges and Universities," University Education, vol. 4, no. 1, pp. 16-19, 2015.

[3] C. L. Guo, "Core competence of students in applied undergraduate colleges and its cultivation," Chinese Vocational and Technical Education, vol. 25, no. 33, pp. 100-102, 2017.

[4] Xie Qisheng, "Some thoughts on cultivating students' core literacy," http://www.chnbloger.com/d8jnh55.htm, 2018-6-30.

[5] Feng Xinrui, "Comprehensive practice and the cultivation of students' core literacy," http://blog.sina.com.cn/s/blog_179452cba0102xhvu.html, 2018-6-30.

[6] K. Ge, "Research on the construction method of practical teaching system in applied undergraduate education," Journal of Shanxi Institute of Energy, vol. 31, no. 2, pp. 63-65, 2018. 